\title{
Mobilization and Stimulation of Neuromuscular Tissue (MASONT) for Stroke Survivors
}

\author{
Dimitrios Athanasiadis ${ }^{1}$, Yannis Dionyssiotis ${ }^{2}$, Jannis Papathanasiou ${ }^{3,4}$, Eleftherios Stefas ${ }^{5}$ \\ ${ }^{1}$ Physical Therapy Department, Rehabilitation Center EVEXIA, Kallikratia, Chalkidiki, Greece \\ ${ }^{2}$ Department of Physical and Rehabilitation Medicine, European Interbalkan Medical Center, Thessaloniki, Greece \\ ${ }^{3}$ Department of Medical Imaging, Allergology \& Physiotherapy, Faculty of Dental Medicine, Medical University of Plovdiv, \\ Plovdiv, Bulgaria \\ ${ }^{4}$ Department of Kinesitherapy, Faculty of Public Health, Medical University of Sofia, Sofia, Bulgaria \\ ${ }^{5}$ Department of Physical Medicine and Rehabilitation, Rehabilitation Center EVEXIA, Kallikratia, Chalikidiki, Greece
}

\section{Correspondence:}

Yannis Dionyssiotis, Department of Physical and Rehabilitation Medicine, European Interbalkan Medical Center, 10 Asklipiou Str., Pylaia, Thessaloniki, 55535, Greece E-mail:yannis_dionyssiotis@hotmail.com; dionyssiotis@gmail.com Tel: +306946469759

Received: 13 July 2016

Accepted: 26 June 2017

Published Online: 31 Aug 2017

Published: 30 March 2018

Key words: cortical reorganization, functional recovery, MASONT, somatosensory intervention, stroke

Citation: Athanasiadis D, Dionyssiotis Y, Papathanasiou J, Stefas E. Mobilization and stimulation of neuromuscular tissue (MASONT) for stroke survivors. Folia Med (Plovdiv) 2018;60(1):158-63.

doi: 10.1515/folmed-2017-0074
Mobilization and Stimulation of Neuromuscular Tissue (MASONT) is a newly invented somatosensory intervention used for the recovery of function in stroke patients. This paper aims to offer a more spherical view on the new technique. To that end, a basic manual of MASONT's application is provided, along with its rational of use. Moreover, clinical observations on the application of the technique and its effects on neurological patients are presented, as well as, a report on its safety.

\section{INTRODUCTION}

Stroke is a disease that occurs at the cerebral vasculature when oxygen cannot be delivered at the brain cells and, as a result, causes cellular death. ${ }^{1}$ Following stroke, some of the affected areas are potentially injured but can recover (penumbra) due to collateral circulation. ${ }^{2}$ To some extent, quickly after an injury and for several weeks and possibly months, neural reorganization and neuroplastic changes are provoked but whether the recovery process is affected positively or negatively by these is under scrutiny. ${ }^{3}$

One of the commonest impairment caused by stroke is weakness of the lower and upper limb. ${ }^{4}$ Upper limb recovery for stroke survivors fails to be copied efficiently. 5,6 Therefore, plenty of 'hands-on' techniques are being applied to stroke patients ${ }^{7}$, such as vibration or tapping. ${ }^{8}$ Most of these techniques have demonstrated a failure to produce a standard of usefulness in functional recovery which, combined with the lack of evidence behind those interventions, reveals a necessity for better comprehension of the recovery mechanisms. ${ }^{9,10}$

Mobilisation and stimulation of neuromuscular tissue (MASONT) is one of those 'hands-on' facilitatory techniques, designed to offer a time-saving and money-saving innovative treatment alternative. MASONT is a technique with a variety of applications based on sensory feedback. ${ }^{11}$

This paper will provide more details on its 
application, its rational of use and the clinical experience about it. Moreover, a short report on the safety of the technique will be outlined.

\section{MATERIALS AND METHODS}

Mobilization and stimulation of neuromuscular tissue (MASONT), at its basic form, involves the application of a transverse stretch across the muscle belly, either on the upper-limb or the lower limb. The area of application is specified and justified, according to the findings of studies on the regional physiology. ${ }^{11}$ Moreover, there should be a progression on the way to apply MASONT's basic technique, depending on the attendance and functional level of the patient. An example of the technique is granted. For one basic application on the upperlimb, the therapist initially brings the thumb over the muscle belly and grips the lower surface of the forearm, keeping the patient's hand in a relaxed

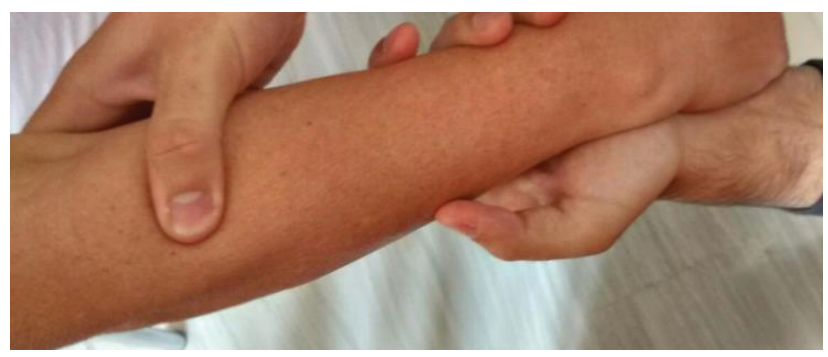

Figure 1.

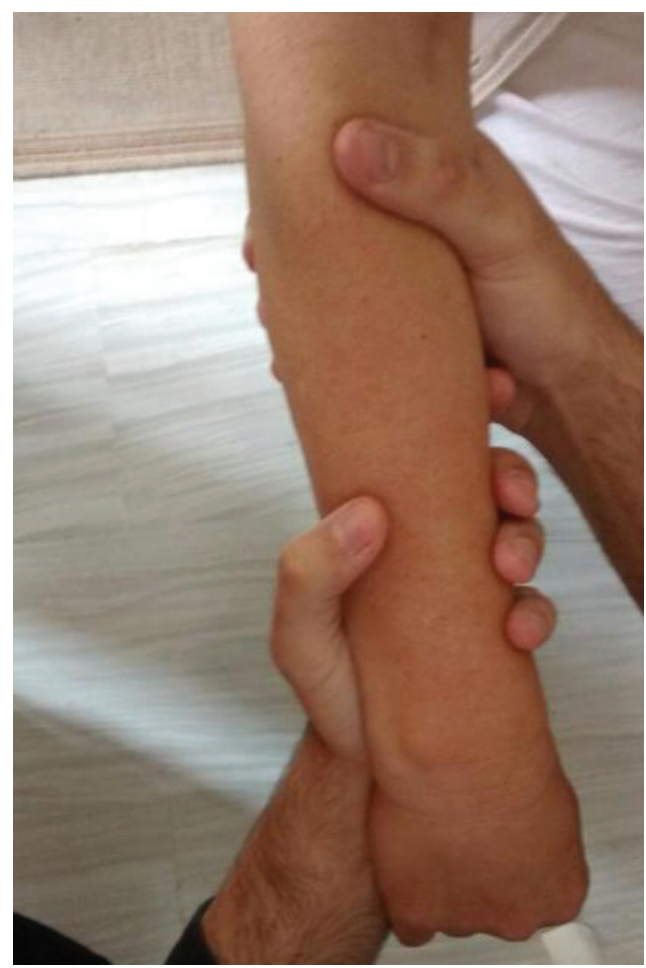

Figure 3. position (Fig. 1). Afterwards, the therapist turns the thumb across the attached muscle belly, offering a bit of compression along the way (Fig. 2). A brisk muscular contraction may be observed, but that is not definite as it depends on the flaccidity level of the limb, as well as on the presence of spasticity which is a contraindication for this specific application. The suggested dosage for this application is 4 times per minute with 15 seconds interval, with repetition every 15 minutes for 5 hours.

Another form of MASONT is the 'twisting'. At the starting position, the therapist supports the forearm with the left hand in a relaxed position and places the thumb of the right hand over the muscle belly (Fig. 3). Afterwards, the therapist applies a continuing transverse stretch on the muscle belly with the right hand and supinates the patient's hand (Fig. 4). The therapist can hold this position for a longer time period, about thirty seconds, and

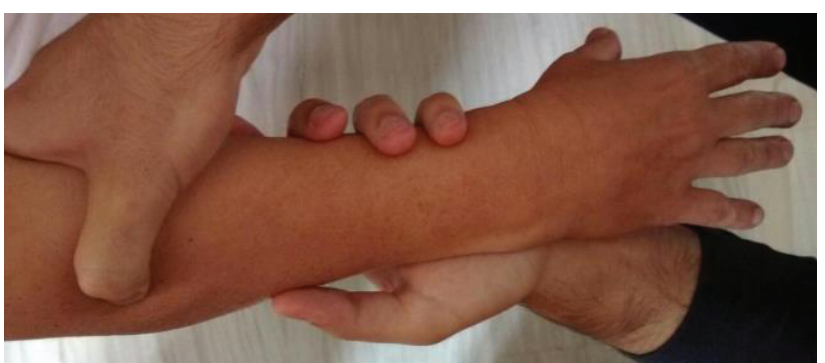

Figure 2.

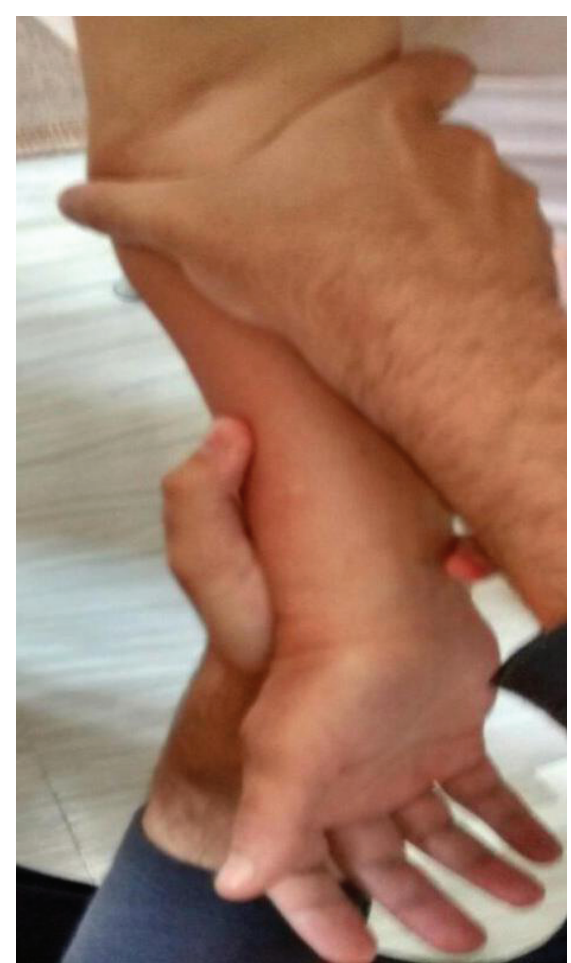

Figure 4. 
then try it again after a while, in an area located lower or higher from the initial application area. This technique can also be used for patients with spasticity, contrary to the one previously displayed.

\section{RESULTS}

Based on a review of interventions that use similar somatosensory stimuli for functional recovery of stroke patients, it is reported that somatosensory interventions can trigger functional recovery through cortical reorganization. ${ }^{11}$ Three trials were the ones that demonstrated the ability of somatosensory interventions to cause functional recovery on stroke survivors by triggering cortical reorganization - a total of 17 out of 23 patients. ${ }^{12-14}$ This possibly validates the theory that recovery depends on cortical circuits which receive the appropriate sensory input from the periphery and reconnect the partially disconnected circuits in order to 'rescue' the repair of the circuits and not 'collapse' the lesioned circuits which would otherwise be the case. Therefore, the therapist offers guided or assisted recovery through perceptual inputs based on bottom-up targeted stimulation. ${ }^{15}$

Facilitation of the alterations in neuroplastic reorganizational mechanisms of the brain is the neural basis of new interventions aiming to provide bigger functional advantages in the recovery of stroke patients. ${ }^{3}$ The majority of evidence showed that somatosensory interventions can elicit cortical reorganization which will initiate a series of phenomena that will finally lead to functional recovery. However, attention should be laid on the patient's area of lesion, as well as the hemiplegic side, in order to render MASONT as helpful as possible, based on the findings of the review. ${ }^{11}$

\section{DISCUSSION}

The technique has never been applied in a form of experiment for reasons of safety, because MASONT is still at a developmental stage. However, at an initial stage, it has been applied tentatively at five cases, only with limited repetitions (maximum five applications in total, twice or thrice per session), only for one session and only the basic technique (Figs 1 and 2). The positive results came from two stroke patients whose motor function presented some improvement. It should be reported that both of the patients had very good level of consciousness, had their hand with no spasticity, but in a flaccid state, and were men over 60 years old, 3 months after stroke. It should also be noted that both of them had left hand hemiplegia with total motor weakness, but not sensory.

The negative results came from three cases. The first case was a 68-year-old man with complete spinal cord injury at L2-L3 without spasticity, where MASONT was applied at the lower limb which had total both motor and sensory weakness. There was no effect of MASONT on either motor or sensory activity. The second case was a 45-year-old woman with tibial neurotmesis in chronic stage with total both motor and sensory weakness, where MASONT was applied at the lower limb. Again, there was no motor or sensory effect. Lastly, a third case of a 73-year-old woman with stroke for 6 months, who also presented with aphasia, spasticity, loss of consciousness and total motor and sensory weakness. There only the basic technique was applied on the right hemiplegic upper-limb, but no effect was shown in terms of either motor or sensory recovery. Concluding, the level of consciousness, spasticity and sensory capacity seem to be affecting the results but, since no relevant literature exists on MASONT, no further discussion could be held.

Apart from its implementation in terms of recovery, there is some consideration that recommends the use of MASONT's basic form as a prognostic tool for recovery of the hemiplegic hand. However, this aspect of MASONT has never been further explored.

Before designing a clinical trial on the effects of MASONT, the clinician should consider the way that MASONT affects the local area that it is applied on. To that extent, a short report on safety is provided. However, as the technique is newly invented, there is no clinical evidence to structure a report of a traditional form. Therefore, the report was mainly an unstructured narrative report of the related literature.

The first aspect to shed light on in terms of the safety of the application is the vascular effects of MASONT locally. It is important to focus on blood supply because axonal transport and impulse propagation depends on regional oxygen supply. ${ }^{16}$ Feeder vessels supply the peripheral nerve with blood from extraneural vessels and even if they are compromised, the neural function will not be defected rendering it relatively independent of static and dynamic condition. The reason for this is that those feeder vessels slack and they can glide keeping unaltered the sufficient blood supply. Moreover, the interface of connective tissue should be taken into consideration when mobilizing the nervous system and, in the occasion of the periph- 
eral nerve, this interface is the fascicle. ${ }^{17}$ There three connective tissue layers are interposed from outer to inner: the epineurium, the perineurium and the endoneurium. There is a longitudinal system of capillary anastomoses between the perineurium and the endoneurium which provides safety to the vessels of the region. ${ }^{16}$ Moreover, there is a perineural diffusion barrier which protects the endoneural environment from exterior pressure (e.g. epineural edema), as well as interior pressure (e.g. an edematous reaction). ${ }^{17}$

Regarding the tissue of a peripheral nerve, a certain period of time is needed for pressure to cause an irreversible deformation or lesion and this can be supported by the fact that $30 \mathrm{~mm} \mathrm{Hg}$ of pressure applied for up to 4 hours cannot cause irreversible changes or even neural damage. ${ }^{16}$ Lastly, the epineurium can easily be injured and even slight trauma due to mild compression may cause epineural edema. ${ }^{17}$ Fifty $\mathrm{mm} \mathrm{Hg}$ applied for 2 hours on the peripheral nerve of a rabbit caused epineural edema. ${ }^{18}$ However, at MASONT the time period of the applied compression is only a few seconds. No literature has focused on the epineurium under that amount of compression. From a biomechanical point of view, injury of nervous tissue can occur either by trauma or entrapment and the mildest level of injury (1st degree) is caused either by prolonged compression with low-pressure or by an event of high-compression; neither of which are a suitable description for MASONT. ${ }^{19}$ Moreover, as reported earlier, duration in the compression is needed to cause damage and also lower compression does not seem to involve mechanical factors in contrast to higher pressure. ${ }^{16}$

Regarding the connective tissue interface of the muscle, this consists, from outer to inner, of the epimysium, the perimysium and the endomysium. These are functionally significant as they maintain the muscular length and shape after mechanical deformation and plenty pathological processes occur at them. ${ }^{20}$ Hence, the therapist should be very informed about any possible pathological condition that might affect that connective tissue, especially for the perimysium because afferent endings are located at it, which are of vital significance in terms of functional recovery, and along with them there are venules, arterioles, nerve fibers and lymphatic vessels. ${ }^{20}$ According to injury biomechanics, the injury of the skeletal muscle tissue can be broadly categorized into three groups: the muscle injury that is induced by exercise, the impact injuries (e.g. contusion) and the muscular strain; none of them has an injury description or injury cause that could fit with the description of the application of MASONT. ${ }^{19}$

Finally, emphasis will be put on the axoplasm, which is the axon's cytoplasm, and it is of vital importance for the axon's normal function because it is used as a mechanism of axon transport, necessary for the movement of cytoskeletal proteins, organelles and vesicles with neuropeptides, as well as the damaged organelles, the plasma membrane and the endocytosis substances. ${ }^{21}$ It is important to focus on the axoplasm and its flow because if it slows, it causes changes to the action potentials. It is reported that axoplasmic flow is affected by mobilization of the nervous system and also mild compression at around $40 \mathrm{~mm} \mathrm{Hg}$ can interrupt the retrograde and antegrade axoplasmic flow. ${ }^{17}$ However, fast axoplasmic transport was unchanged at $20 \mathrm{~mm}$ $\mathrm{Hg}$ under 2 hours of pressure on rabbits. ${ }^{22}$ Additionally, $20 \mathrm{~mm} \mathrm{Hg}$ of pressure did not change the fast axoplasmic flow but even at $60 \mathrm{~mm} \mathrm{Hg}$ applied for 4 hours did not cause irreversible effects on the axoplasmic flow of rabbits. ${ }^{23}$ Concluding, intracellular mobility of the axoplasmic transport systems transfer many helpful substances (e.g. neurotrophic factors) to the cytoplasm and through MASONT the therapist most possibly does not seem to be affecting the axoplasmic flow negatively given that the applied force is applied for lower amount of time. ${ }^{17}$

\section{CONCLUSION}

MASONT is a newly invented technique used for functional recovery of the upper and lower limb of stroke survivors. The way to apply some basic forms of the technique is shown. The reason to apply MASONT is to elicit cortical reorganization through its somatosensory stimuli and thus offer functional recovery. According to similar somatosensory interventions, and based on clinical observations, this rational of use can be supported, but only partially due to the low number of rigorously-organized trials yet conducted. Finally, explanations are given on the way that MASONT could affect the normal physiology of the application area and it is advised that the therapist should assess the area thoroughly, before applying the technique. Future clinical trials remain to be conducted in order to prove or deny the hypothesis about MASONT's usefulness in clinical practice. 


\section{ACKNOWLEDGEMENTS}

Mr. Athanasiadis would like to thank the consultation support provided to him by Dr. Sue Hunter and Dr. Panos Barlas during his Master Thesis at Keele University.

\section{REFERENCES}

1. Bartels MN. Pathophysiology, medical management and acute rehabilitation of stroke survivors. In: Gillen G, editor. Stroke rehabilitation: a function-based approach. 3rd ed. St. Louis, MO: Elsevier Mosby; 2011. p. 2.

2. Verheyden G, Ashburn A. Stroke. In: Stokes M, Stack E, eds. Physical management for neurological conditions. 3rd ed. Edinburgh: Elsevier; 2011. p. 11-2.

3. Nudo RJ. Neural bases of recovery after brain injury. J Commun Disord 2011;44(5):515-20.

4. Warlow C, van Gijn J, Dennis M, et al, editors. Stroke: practical management. 3rd ed. Malden, MA: Blackwell Publishing; 2008. p. 583.

5. Kwakkel G, Kollen BJ, van der Grond J, et al. Probability of regaining dexterity in the flaccid upper limb impact of severity of paresis and time since onset in acute stroke. Stroke 2003;34(9):2181-86.

6. Broeks JG, Lankhorst GJ, Rumping K, et al. The long-term outcome of arm function after stroke: results of a follow-up study. Disability and rehabilitation 1999;21(8):357-64.

7. Jackson J. Specific treatment techniques. In: Stokes M, Stack E, editors. Physical management for neurological conditions. 3rd ed. Edinburgh: Elsevier; 2011. p. 244.

8. Umphred DA, Byl NN, Lazaro RT, et al. Interventions for clients with movement limitations. In: Umphred DA, Lazaro RT, Roller ML, et al., editors. Umphred's neurological rehabilitation. 6th ed. St. Louis, MO: Elsevier Mosby; 2013. p. 202-34.

9. Langhorne P, Bernhardt J, Kwakkel G. Stroke rehabilitation. The Lancet 2011;377(9778):1693-1702.

10.Langhorne P, Coupar F, Pollock A. Motor recovery after stroke: a systematic review. The Lancet Neurology 2009;8(8):741-54.

11. Athanasiadis D. Physiology underpinning Mobilization and Stimulation of Neuromuscular Tissue (MASONT): a review. [Master's Thesis] University of Keele, Keele, United Kingdom. Available from: https://www.researchgate.net/ publication/303288344_Physiology_underpinnin
g_Mobilization_and_Stimulation_of_Neuromuscular Tissue MASONT a revi ew.

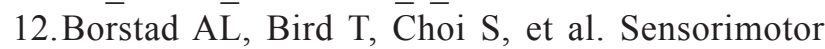
training induced neural reorganization after stroke: a case series. J Neurol Phys Ther 2013;37(1):27-36.

13. Dechaumont-Palacin S, Marque P, De Boissezon X, et al. Neural correlates of proprioceptive integration in the contralesional hemisphere of very impaired patients shortly after a subcortical stroke: an FMRI study. Neurorehabilitation and neural repair. 2008; 22(2): 154-65.

14. Nelles G, Jentzen W, Jueptner M, et al. Arm training induced brain plasticity in stroke studied with serial positron emission tomography. Neuroimage 2001;13(6):1146-54.

15. Robertson IH, Murre JM. Rehabilitation of brain damage: brain plasticity and principles of guided recovery. Psychological bulletin 1999;125(5):544.

16. Rydevik B, Lundborg G, Olmarker K, et al. Biomechanics of peripheral nerves and spinal nerve roots. In: Nordin M, Frankel VH, editors. Basic biomechanics of the musculoskeletal system. 4th ed. Baltimore, MD; Philadelphia, PA: Wolters Kluwer Health in association with Lippincott, Williams \& Wilkins; 2012. pp.131-2, 140.

17. Butler DS, editor. Mobilisation of the nervous system. Melbourne, New York: Churchill Livingstone; 1991. pp. 19, 22, 24-6, 36-7, 55-6, 62, 64.

18. Rydevik B, Lundborg G. Permeability of intraneural microvessels and perineurium following acute, graded experimental nerve compression. Scand J Plast Reconstr Surg 1977;11(3):179-87.

19. Whiting WC, Zernicke RF, editors. Biomechanics of musculoskeletal injury. 2nd ed. Champaign, IL: Human Kinetics; 2008. pp. 144-7, 150.

20. Mense S. Functional anatomy of muscle: Muscle, nociceptors and afferent fibers. In: Mense S, Gerwin $\mathrm{RD}$, editors. Muscle pain: understanding the mechanisms. Berlin, London: Springer; 2010. pp. 18-28.

21. VanPutte CL, Regan JL, Russo AF, editors. Seeley's anatomy and physiology. 10th ed. New York, NY: McGraw-Hill; 2014. p. 365.

22. Dahlin LB, McLean WG. Effects of graded experimental compression on slow and fast axonal transport in rabbit vagus nerve. J Neurol Sci 1986;72(1):19-30.

23. Hahnenberger RW. Effects of pressure on fast axoplasmic flow. An in vitro study in the vagus nerve of rabbits. Acta Physiol Scand 1978;104(3):299-308. 


\title{
Мобилизация и стимуляция нервно-мышечной ткани (MASONT) у пациентов после инсульта
}

\author{
Димитриос Афанасиадис ${ }^{1}$, Янис Дионисиотис ${ }^{2}$, Янис Папатанасиу ${ }^{3,4}$, Элефтериос Стефас ${ }^{5}$ \\ ${ }^{1}$ Кафедра физиотерапии, Реабилитационный центр Эвексия, Калликратия, Халкидики, Греция \\ 2 Кафедра физиотерапии и реабилитации, Европейский медицинский центр Интербалкан, Салоники, Греция \\ ${ }^{3}$ Кафедра образной диагностики, дентальной аллергологии и физиотерапии, Факультет дентальной медицины, Медицин- \\ ский университет - Пловдив, Пловдив, Болгария \\ ${ }^{4}$ Кафедра кинезитерапии, Факультет общественного здравоохранения, Медицинский университет - София, София, Болгария \\ ${ }^{5}$ Кафедра физиотерапии и реабилитации, Реабилитационный центр Эвексия, Калликратия, Халкидики, Греция
}

Адрес для корреспонденции: Янис Дионисиотис, Кафедра физиотерапии и реабилитации, Европейский медицинский центр Интербалкан, ул. „Асклипиу" 10 Пилеа, Салоники, 55535, Греция

E-mail:yannis_dionyssiotis@ hotmail.com; dionyssiotis@gmail. com

Tel: +306946469759

Дата получения: 13 июля 2016 Дата приемки: 26 июня 2017 Дата онлайн публикации: 31 августа 2017

Дата публикации: 30 марта 2018

Ключевые слова: кортикальная реорганизация, функциональное восстановление, MASONT, соматосенсорные стимулы, инсульт

\section{Образец цитирования:}

Athanasiadis D, Dionyssiotis

Y, Papathanasiou J, Stefas E. Mobilization and stimulation of neuromuscular tissue (MASONT) for stroke survivors. Folia Med (Plovdiv) 2018;60(1):158-63.

doi: 10.1515/folmed-2017-0074
Мобилизация и стимуляция нервно-мышечной ткани (MASONT) является новоразработанной методикой в области соматосенсорной терапии для функционального восстановления больных после инсульта. Данное сообщение имеет целью представить подробное описание новой методики. С этой целью нами представлено основное руководство по применению MASONT с указаниями наиболее рациональных способов применения. Дополнительно представлены клинические наблюдения при применении методики и её эффективности при лечении неврологических больных, вместе с докладом о безопасности применения. 